\title{
Evaluation of Synthetic Zirconyl Complex as Potential Floral Preservative on Postharvest Quality of Cut Roses Rosa hybrida L. Cv. Grand prix Fetouh, M. I. ${ }^{1}$ and K. M. Saad-Allah' ${ }^{2}$. \\ ${ }^{1}$ Horticulture Department, Faculty of Agriculture, Tanta University, Tanta, Egypt \\ ${ }^{2}$ Botany Department, Faculty of Science, Tanta University, Tanta, Egypt
}

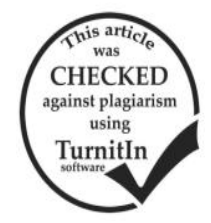

\section{ABSTRACT}

Floral preservative biocides in most cases consider toxic at the affective concentration to both plant and microbial proliferation. Therefore, in order to find nontoxic biocide, this experiment was conducted to evaluate a recent Synthetized Zirconyl Complex as a potential floral preservative biocide for cut roses (Rosa hybrida L. cv. Grand Prix). To assess the effect of Zirconyl biocide as potential preservative, cut roses was treated with $0,10,20$ and $50 \mathrm{ppm}$ plus $20 \%$ sucrose as pulse solution for 24 hours before transferred into holding solution 10 times dilution from the pulsing solution. The flower quality such as the vase life, flowers relative fresh weight and maximum flower diameter were observed. Also, flower water relation parameters were determined, besides evaluating the biochemical responses such as chlorophyll degradation and florescence, total soluble sugars, free amino acids, DPPH free radical scavenging activity, total phenolic compounds and total flavonoids were determined. Results indicated the possibility to use Zirconyl complex biocide as floral preservative at 20-50 ppm concentration to extend the cut rose flowers vase life of from 8.88 to 13 day through improving flower water relation parameters and reducing oxidative damage.

Keywords: Rose, Zirconyl, Vase life, water relation, chlorophyll, fluorescence, DPPH.

\section{INTRODUCTION}

Roses (Rosa hybrida L.), the most important ornamental species of Rosaceae family, are recognized for their high economic value. Vase life of rose cut flowers is usually short Shaman, (2012). Floral preservative solution consider is a preferred environment for microbial proliferation as it holds needed resources of water and sugars essential for reproduction. The microbial proliferation surrounding flowers stems rabidly causes vascular occlusion which reduce and/or prevent water uptake Jowkar et al., (2012) which consider the major cause of quality deterioration and vase life reduction.

Therefore, the target of cut flower market is to control and minimize microbial proliferation to extend quality and longevity of cut flowers, mainly roses. Conversely functional biocides are expected to affect flowers physiological properties particularly their photosynthetic system function by their toxic compounds during aging and senescence Jowkar et al., (2012). None of the biocides had a consistent and high anti-bacterial effect at concentrations that are not toxic to flowers. Knee, (2000).

Some of these biocides such as silver nitrate and silver thiosulphate are considered hazard chemical and risk to environment and health Damunupola and Joyce, (2006). A recent Zirconyl Complex based on azo dye ligands have been Synthetized on the Department of Chemistry, Faculty of Science, Tanta University. The Synthetic Zirconyl complex were tested in-vitro for their antimicrobial activity against different types of bacteria and fungi. In most cases, the ligands and complexes were active against both tested bacteria and fungi. The importance of the hetyerocyclic azodyes stems from their biological activities such as inhibition of DNA, RNA, protein synthesis, carcinogenesis and biological activity Khedr et al., (2014).

The biocidal role of the complex had been investigated, but how plant tissues respond to it and if it toxic to plants or not wasn't investigated. To be used as floral preservative biocide, plant physiological responses such as chlorophyll degradation, chlorophyll fluorescence and plant antioxidant mechanisms still need more evaluation. Therefore in order to found an easy to use, nontoxic and inexpensive compound for large scale application; we have focused on the mentioned physiological properties beside flower quality assessment to evaluate biocidal efficacy of Zirconyl Complex as floral preservative biocide for cut rose flowers (Rosa hybrida L. cv. Grand Prix)

\section{MATERIALS AND METHODS}

The experiment toke place at the Botany Laboratory, Faculty of Science Tanta University at January 2014 to evaluate the recent synthetic Zirconyl Complex as a potential preservative biocide in the cut flower market of Rosa hybrida L. cv. Grand Prix.

Plant material: Cut rose (Rosa hybrida L. cv. Grand Prix), flowers were purchased from a flora mix Egypt commercial cut flower growers in Giza, Egypt. The cut flowers were harvested at normal harvest maturity when sepals starting to reflex Shaman, (2012). They were immediately stood upright into buckets partially filled with tap water and transported within 3 hours to the botany laboratory at faculty of science Tanta University. To minimize moisture loss, the cut flowering stems were enclosed with plastic film during transport.

In the laboratory, uniform flowers free of visual defects were used in the experiments. Prior to treatments, the stems were re-cut under distilled water to $35 \mathrm{~cm}$ length to eliminate air blockage in the stem. Lower leaves were removed from each stem to insure that leaves out of the vase are used to hold the flowers. Rose flower stems were held individually in $200 \mathrm{ml}$ glass vases each containing $150 \mathrm{ml}$ of vase solution. The vase opening was covered with a low density polyethylene film sheet to minimize contamination and prevent evaporation.

Preservative solution preparation: Solutions were freshly prepared at the beginning of experiments.by dissolving the Zirconyl complex in $0.2 \%$ DMSO before reaching the final volume using distilled water. The Complex Molecular formula and analysis are presented in Table (1) quoted after Khedr et al., (2014), the complex structure is presented in Fig (1). 
Table 1. Complex formula and characteristics:

\begin{tabular}{|c|c|c|c|c|c|c|c|}
\hline \multirow[t]{2}{*}{ Complex Molecular formula } & \multirow{2}{*}{$\begin{array}{c}\text { Mol. Wt. } \\
\text { (Cal. M. Wt.) }\end{array}$} & \multirow{2}{*}{$\begin{array}{c}\text { Color } \\
\left(\Delta_{\mathrm{m}}\right)\end{array}$} & \multicolumn{5}{|c|}{$\begin{array}{c}\text { Microanalysis } \\
\text { Found \% (Calcd.) }\end{array}$} \\
\hline & & & $\% \mathrm{C}$ & $\% \mathbf{H}$ & $\% \mathbf{N}$ & $\% \mathrm{Cl}$ & $\% \mathbf{M}$ \\
\hline $\begin{array}{l}\left.\mathrm{ZrO}\left(\mathrm{L}^{4}\right)_{2}\right] \\
\left(\mathrm{C}_{16} \mathrm{H}_{10} \mathrm{BrN}_{10} \mathrm{O}_{3} \mathrm{Zr}\right)\end{array}$ & $\begin{array}{c}641.76 \\
(641.35)\end{array}$ & $\begin{array}{l}\text { Brown } \\
(2.18)\end{array}$ & $\begin{array}{c}29.65 \\
(29.96)\end{array}$ & $\begin{array}{c}1.99 \\
(1.57)\end{array}$ & $\begin{array}{l}11.33 \\
(10.92)\end{array}$ & $\begin{array}{c}6.02 \\
(5.53)\end{array}$ & $\begin{array}{r}14.62 \\
(14.22)\end{array}$ \\
\hline
\end{tabular}

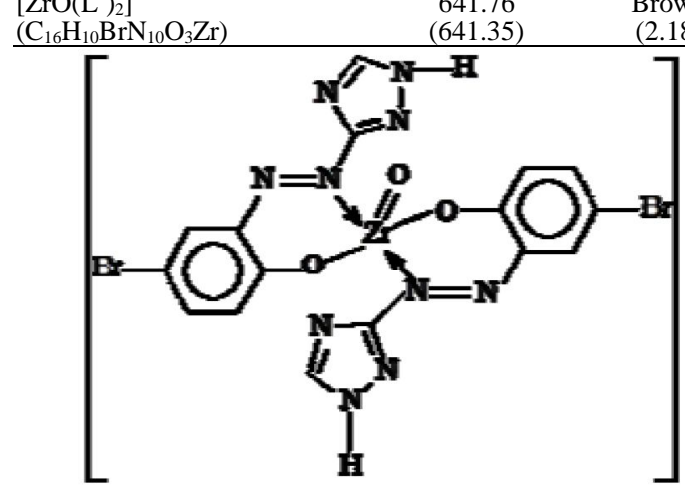

Fig. 1.Structure representation of Zirconyl (II) complexes. Experimental design and treatments:

Flowers were arranged in a completely randomized design of 4 treatments. The treatment were replicated three times and each replicate consisting of nine flowers. Treatments applied as vase solutions were $0,10,20$ and $50 \mathrm{ppm}$ plus $20 \%$ sucrose as pulse solution for 24 hours, then flowers were transferred into holding solution 10 times dilution from the pulsing solution plus $2 \%$ sucrose. During the experiment, the flowers were held in controlled growth cabinet at $20 \pm 2^{\circ} \mathrm{C}$, relative humidity of $60 \pm 10 \%$, and light from cool white florescent tubes with $12 \mathrm{~h}$ of light.

Flower quality assessment:

Vase life was evaluated by checking the flowers appearance and condition, termination of vase life was recorded when wilting of the outer 5 petals occurred or bent neck was observed.

Maximum flower head diameter $(\mathrm{cm})$ were daily measured to evaluate the bud size difference between treatments.

Assessment of water relation of cut roses: The fresh weight of cut flowers and the amount of water uptake were measured daily. The weight of vases without and with the flower was separately recorded in order to calculate:-

Relative fresh weight (RFW) of stems was calculated as \% of initial fresh weight using $\mathrm{He}$ et al., (2006) equation $\mathrm{RFW}=(\mathrm{FWt} / \mathrm{FWt}-0) \times 100$, where, FWt is the fresh weight of stem $(\mathrm{g})$ at $\mathrm{t}=$ day 2, 3, $4, \ldots 10$, and FWt-0 is the fresh weight of the same stem (g) at $\mathrm{t}=$ day 0

Daily water uptake $\left(\mu \mathrm{L}\right.$ day ${ }^{-1} \mathrm{~g}^{-1}$ fresh weight) was calculated as water uptake $\left(\mu \mathrm{L}\right.$ day $^{-1} \mathrm{~g}^{-1}$ fresh weight $)=(\mathrm{St}-1)-\mathrm{St}$, where, $\mathrm{St}$ is weight of vase solution (g) at $\mathrm{t}=$ day $2,3,4 \ldots 10$, and St-1 is weight of vase solution (g) on the previous day. Ahmad et al., (2011).

Daily water loss was calculated as water loss $\left( \pm \mu \mathrm{L}\right.$ day ${ }^{-1} \mathrm{~g}^{-1}$ fresh weight $)=(\mathrm{Ct}-1)-\mathrm{Ct}$, where, $\mathrm{Ct}$ is the combined weights of the cut stem and vase $(\mathrm{g})$ at $\mathrm{t}=$ day $2,3,4, \ldots, 10$, and Ct- 1 is the combined weight of the stem and vase $(\mathrm{g})$ on the previous day.

The difference between water uptake and water loss was expressed as the water balance
Flower Physiological responses:

Chlorophyll Degradation: Total chlorophyll were determined in detached leaf samples on day $2,4,6,8$, and 10 using $85 \%$ cold acetone for extraction and their color intensities were measured by using a spectrophotometer (SPECTRONIC $20 \mathrm{D}$ ) as $\mathrm{mg} / \mathrm{g}$ fresh weight following Sadasivam and Manickam, (1992) method.

Chlorophyll Fluorescence: The quantum efficiency of open photosystem II centers $(\mathrm{Fv} / \mathrm{Fm})$, was measured according to method described by Jowkar et al., (2012) on all the stems leaves on day 2, 4, 6, 8, and 10 with Opti-Sciences OS-5P pulse amplitude fluorimeter (OptiSciences INC., Hudson, NH, USA).

The total soluble sugars concentrations $\mathrm{mg} / \mathrm{g}$ D.W. were determined in detached leaf on day 8 when the vase life of control flowers was terminated according to Herbert et al. (1971).

DPPH Radical Scavenging Assay: The DPPH assay was used to determine the radical scavenging activity of the seed methanolic extracts according to the method reported by Brand-Williams et al., (1995). The percentage of decolourisation was obtained spectrophotometrically at $517 \mathrm{~nm}$ using JENWAY 6315 UV/Visible Spectrophotometer (Japan). DPPH radical scavenging activity (\%) was calculated as [(Abs Control-Abs Sample)/Abs Control] $\times 100$

Analysis of total phenolic compounds content $\mathrm{mg} / \mathrm{g} \mathrm{D.W}$. was quantitativeley estimated by the method described by Jindal and Singh, (1975) using a standard curve prepared by using different concentrations of gallic acid

Estimation of total flavonoids content was performed following the Aluminium chloride colorimetric technique Chang et al., (2002) as mg/g D.W.

Determination of free amino acids content $\mathrm{mg} / \mathrm{g}$ D.W was analyzed by Ninhydrin assays using glycine as a standard according to Lee and Takahashi, (1966).

Statistical analysis of results: Four treatments of three replicates each, were arranged in a randomized complete (RCD) design. The experiment was performed twice and the results were combined for two experiments $(n=6)$ and analysis of variance (ANOVA) was performed using MSTAT-C program, USA Bricker, (1991). Means were compared by the LSD test at P = 0.05 according to Sendecor and Cochran, (1982).

\section{RESULTS}

Effect of potential preservative Zirconyl Complex on Vase life and flower quality.

Results indicated that Zirconyl complex was successful to prolong the vase life of rose cut flowers (Fig. 2). All treatment significantly recorded longer vase life compared to untreated flowers. The maximum vas life 13 days resulted from $20 \mathrm{ppm}$ treatment compared to 8.88 days for the control treatment. 
In the same time, Zirconyl treatment enhanced the quality of rose cut flowers by maximizing the flower diameter. All treatments increased flower diameter compared to control. The maximum flower diameter was reached by the $8^{\text {th }}$ day. The maximum flower diameter was recorded for 20 or $50 \mathrm{ppm}$ treatment without significant different. The maximum value in this concern was recorded for $20 \mathrm{ppm}$ treatment as recorded $9.68 \mathrm{~cm}$ diameter compared to $8.53 \mathrm{~cm}$ for control treatments.

Treatments of Zirconyl complex treatment not only enhanced the vase life and maximum flower diameter, but also maintained higher relative fresh weight. The highest relative fresh weight was reached at the $6_{\text {th }}$ day then declined again till the end of vase life. Treatment of $20 \mathrm{ppm}$ followed by $50 \mathrm{ppm}$ maintained the highest relative fresh weight (131.25 and $128.77 \%$ of initial fresh weight, respectively).
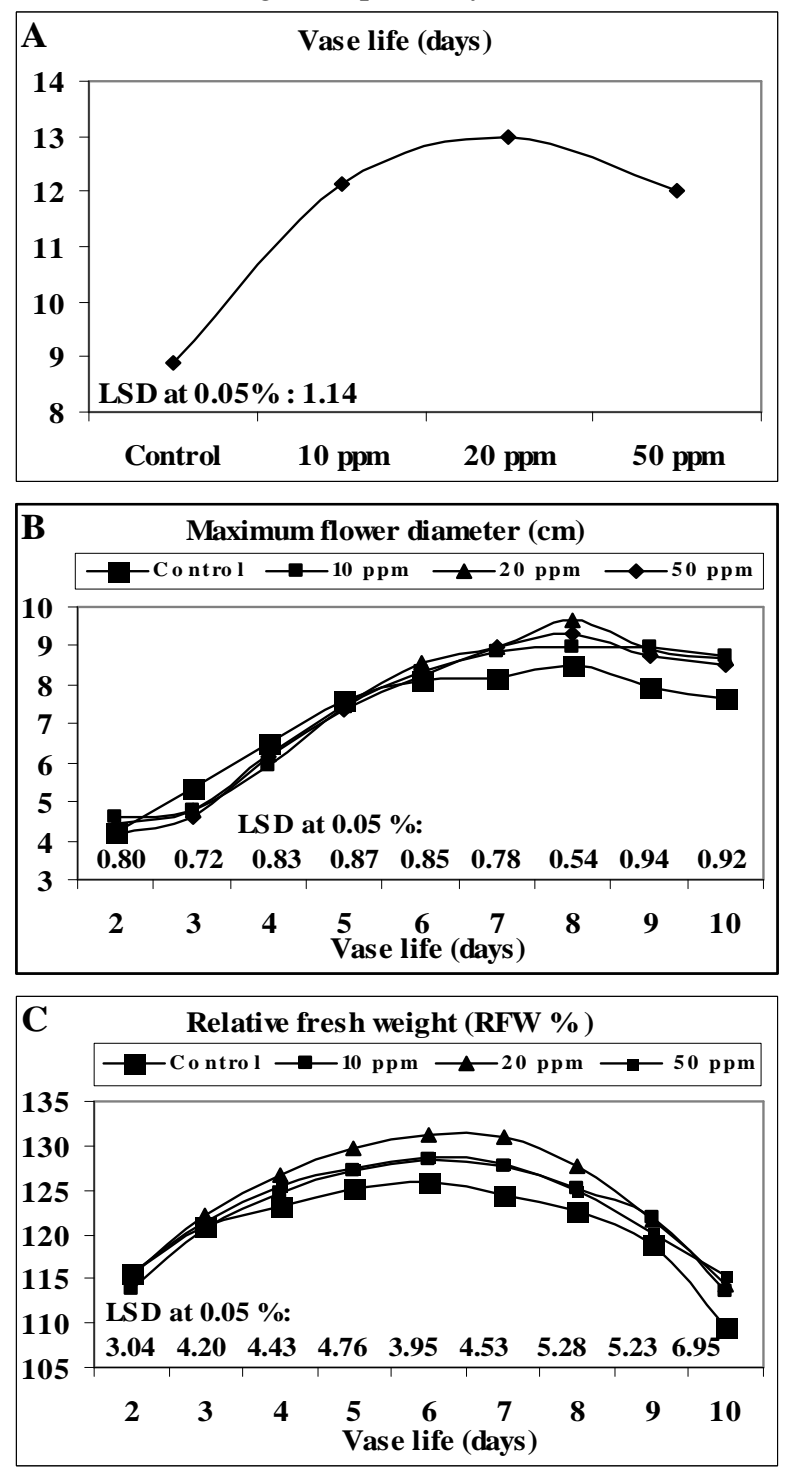

Fig. 2. Effect of Zirconyl complex treatment on vase life (A) maximum flower diameter (B) and relative fresh weight (C) of Rosa hybrida L. cv. Grand Prix cut roses

Effect of potential biocide Zirconyl Complex on rose cut flower water relations.

Using Zirconyl complex as postharvest biocides significantly enhanced water uptake and loss by Rosa hybrida L. cv. Grand Prix cut roses (Fig. 3). All levels of Zirconyl complex minimized water uptake and loss by flowers compared to control. Both water uptake as well as loss was decreased within the flower vase life to reach its minimum at the end of the experiment. Begging from the fifth day of flower vase life the lower values for water uptake and water loss (220 and 209 $\mu \mathrm{L} /$ day/g F.W.) was recorded for $50 \mathrm{ppm}$ treatment followed by $20 \mathrm{ppm}$ treatment in the second place for the rest of the flower vase life whereas all treatment recorded the same significant values compared to control treatment.

The balance between water uptake and water loss reveal the status of internal tissues activities of flower. As long as the water balance is positive, means that the flower is not suffering from water losing from tissues. All treatments recorded positive water balance till the six $^{\text {th }}$ day before the water loss become greater than water uptake. By the end of vase life only 20 and 50 ppm treatments significantly minimized water loss values compared to other treatments.
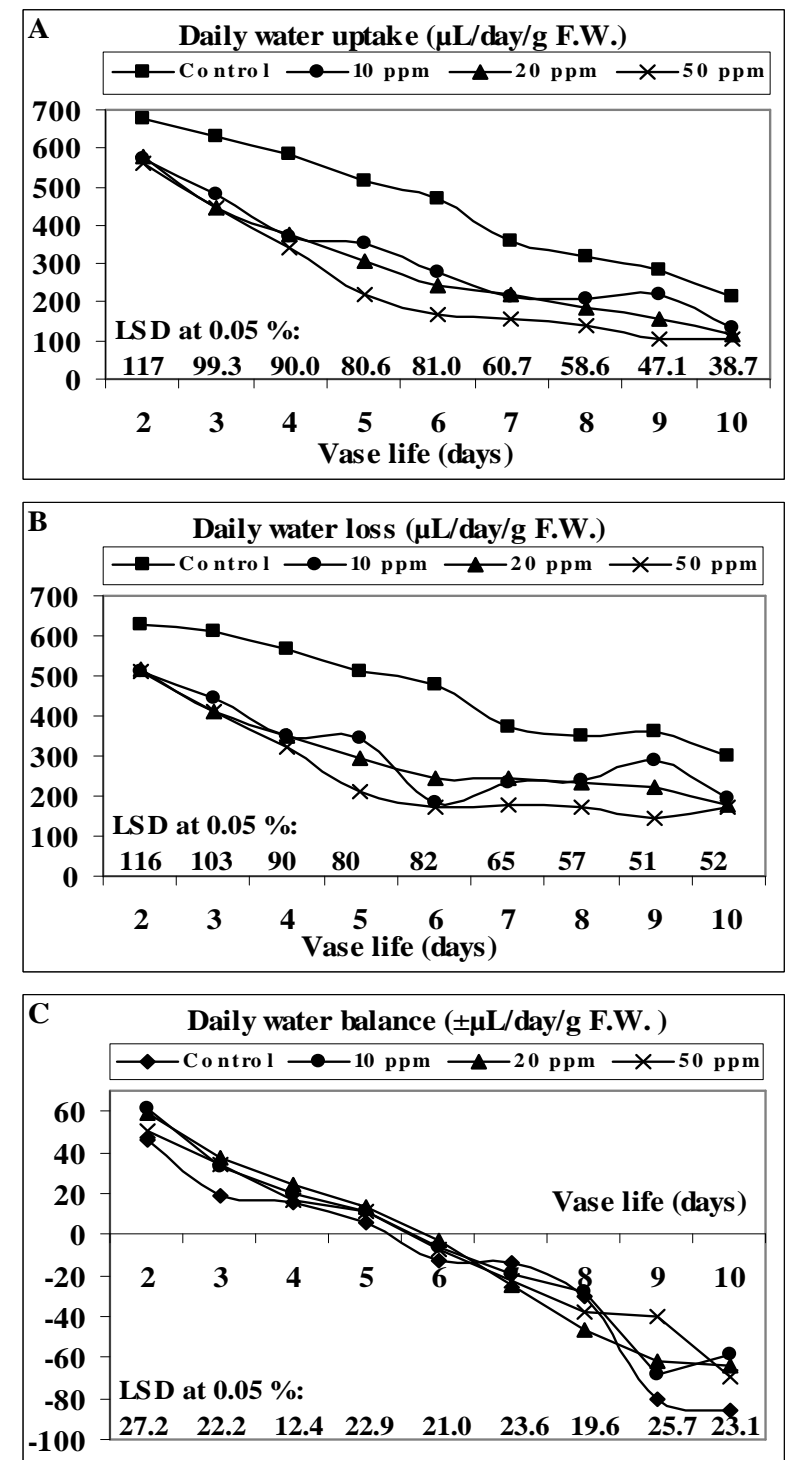

Fig. 3. Effect of Zirconyl complex treatment on daily water uptake (A), daily water loss (B) and daily water balance (C) of Rosa hybrida L. cv. Grand Prix cut roses. 
Effect of potential biocide Zirconyl Complex on rose cut flower physiological parameters

Using Zirconyl Complex as a preservative component affected chlorophyll degradation during rose vase life (Fig.4). Till the $6^{\text {th }}$ day all plants treated with Zirconyl Complex maintained higher chlorophyll content compared to control without significant differences between treatments. By the end of vase life only higher concentration was potent in this respect.
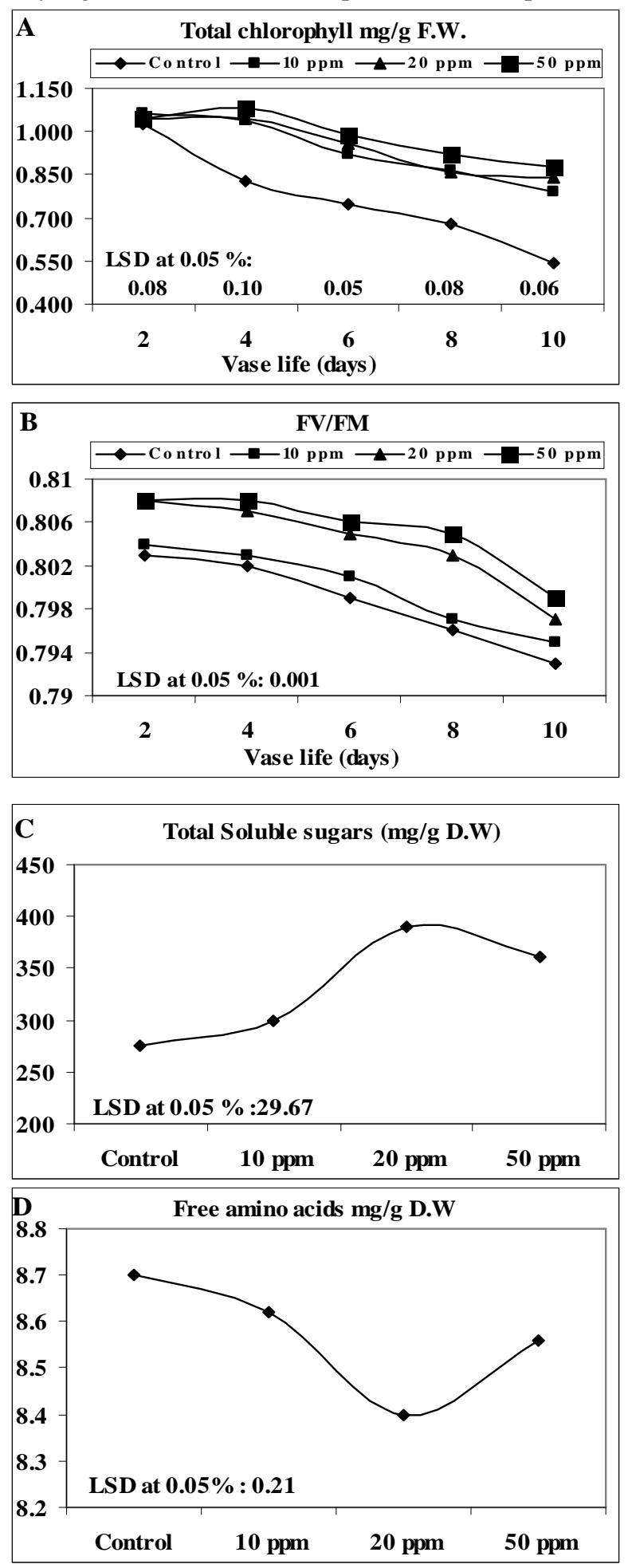

Fig. 4. Effect of Zirconyl complex treatment on total chlorophyll degradation (A), FV/FM (B), total soluble sugars $(C)$ and free amino acids content (D) of Rosa hybrida L. cv. Grand Prix cut roses.
Zirconyl preservative not only retarded chlorophyll degradation but also enhancement of PSII photochemical efficiency measured by $\mathrm{Fv} / \mathrm{Fm}$. Rose flowers treated with 50 and $20 \mathrm{ppm}$ respectively kept higher $\mathrm{Fv} / \mathrm{Fm}$ values till the end of the experiment. As indicated in Fig. (4) Leaves of flowers treated with higher concentration of Zirconyl preservative recorded higher concentration of total soluble sugars, treatment of $20 \mathrm{ppm}$ recorded the highest values of T.S.S. Meanwhile the same treatment recorded the lowest concentration of free amino acids $8.4 \mathrm{mg} / \mathrm{g} \mathrm{D.W}$. while other treatment had no significant difference compared to untreated plant.

Effect of potential biocide Zirconyl Complex on rose cut flower antioxidant responses

Treatment of Zirconyl not only affected water relation of Grand Prix cut roses but also recorded significant differences for all plant physiological responses (Fig. 5).
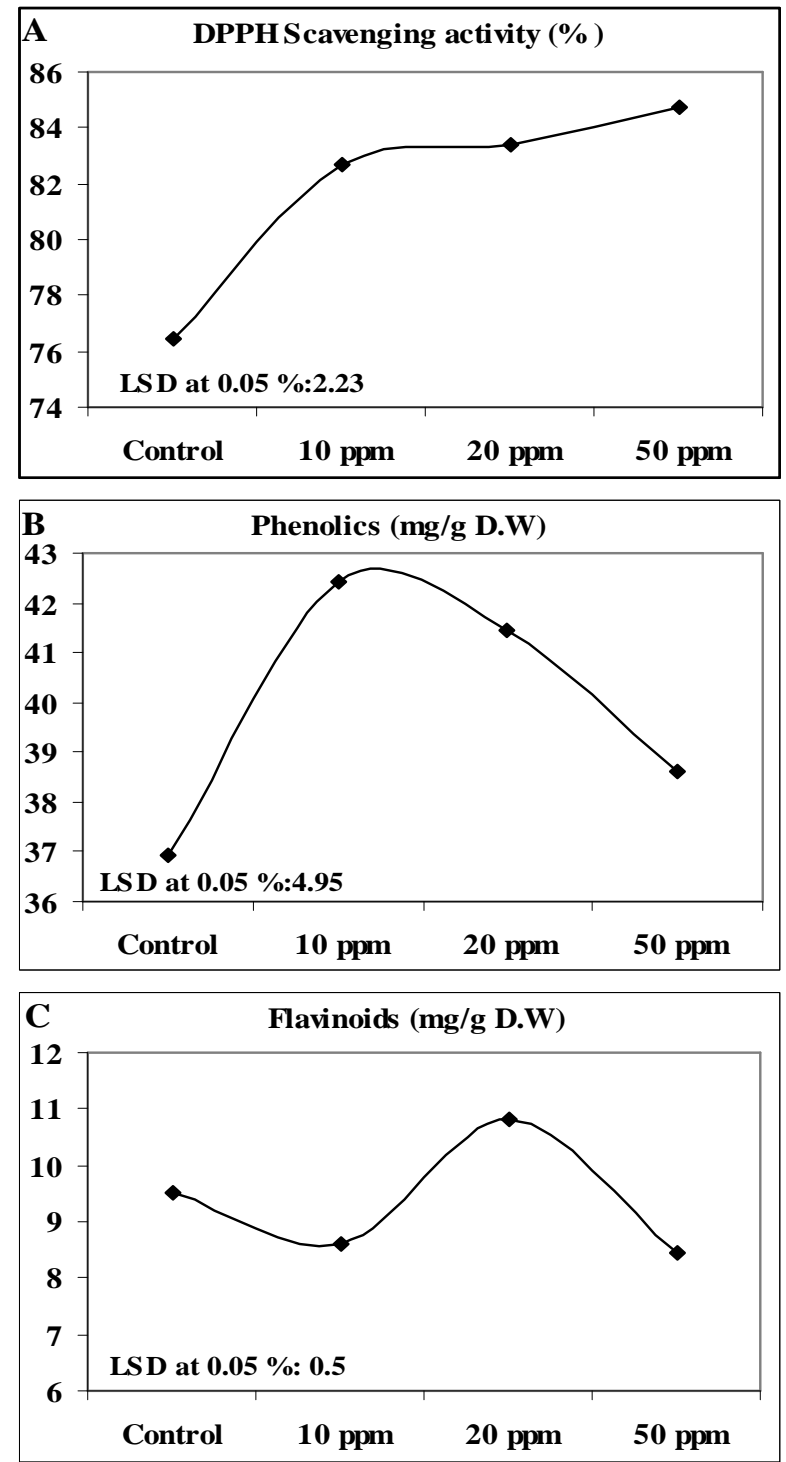

Fig.5. Effect of Zirconyl complex treatment on DPPH Scavenging activity (A), phenolic contents (B), and flavonoid content (C) of Rosa hybrida L. cv. Grand Prix cut roses.

Free radical scavenging activity (DPPH activity) shows a gradual increase within increasing Zirconyl 
complex concentration. However the uppermost DPPH activity $84.73 \%$ was recorded for $50 \mathrm{ppm}$ treatment without significant differences between 10 and $20 \mathrm{ppm}$.

Meanwhile Phenolic compounds as a potent antioxidant compounds showed hewed a non-significant variations between all of Zirconyl complex concentrations. Only the treatment of $10 \mathrm{ppm}$ recoded significant increase compared to control.

Phytochemical flavonoids, the low molecular weight polyphenolic secondary metabolic compounds seems to follow almost similar pattern. Flower treated with $20 \mathrm{ppm}$ recoded the highest flavonoids content $10.81 \mathrm{mg} / \mathrm{g}$ D.W. followed by $9.5 \mathrm{mg} / \mathrm{g} \mathrm{D}$.W. for 50 ppm treatment.

\section{DISCUSSION}

Generally, Zirconyl complex proved to be effective floral preservative biocide without obvious toxicity symptoms. In most cases, effective biocides can be toxic to flower Jowkar et al., (2012). In our experiment, by the end of flower life a visual growth of lateral auxiliary buds were seen elongated in the flower stems and leaves were turgid and fresh. As an active biocide tested against both bacteria and fungi Khedr et al., (2014), Zirconyl complex succeeded to prolong Grand Prix Cut rose's vase life. All treatment increased vase life by 46.4 to $35.13 \%$ compared to control treatment.

In the same time the flower quality was maximized, the flower diameter was increasing for all treatment including control till the six $^{\text {th }}$ day as control flowers shows no further increase after that. Meanwhile other treatment continued increasing flower diameter to reach its maximum at day 8. Zirconyl complex treatments not only delayed flower opening but also increase the flower diameter that the flower can grow to reach. In this experiment the flower lasted for about 4 days before it begins to welt down to declare ending vase life. The previous observation can be referred to the higher relative fresh weight of the flower stems during the vase life. Decline of relative fresh weight can causes some physiological disorders such as life reduction, lack of flower opening Bleeksma and van Doorn, (2003) and wilting of the leaves accompanied by improper opening and wilting of flowers Torre and Fjeld., (2001).

Relatively higher fresh weight is mostly due to inhibition of microorganism proliferation in vase solution and thus preventing stem basal end occlusion by microbes Van Doorn, (1996). Therefore, controlling or reducing microbial proliferation using Zirconyl complex extended the vase life of roses via maintaining higher water relation and balance. The data indicated that rose stems kept in Zirconyl floral preservative exhibited high water balance while minimized the water loss by the flower stem. As seen in (Fig. 3) a gradual decrease in water uptake and loss was observed till the six ${ }^{\text {th }}$ day with a positive water balance for all treatment followed by a negative balance after that with the minimum negative water balance in favor of Zirconyl complex treatments. Increasing water loss is the main cause of flower quality degradation, water loss is mostly due to stem blockage by the bacteria Liu et al. (2009) or by malfunction of membrane permeability caused by toxic biocide compounds during postharvest development and aging Jowkar et al., (2012).

On the other hand, applied biocides could also severally affect other physiological aspects of cut flowers i.e. photosynthetic function and by their toxic compounds during postharvest development and aging Jowkar et al. (2012). Flower stems under Zirconyl complex floral preservative stunted chlorophyll degradation and displayed higher content PSII photochemical efficiency (Fv/Fm). Delaying chlorophyll content degradation in cut flowers may be due to water relation improvement as indicated in (Fig. 3). Chlorophyll degradation is associated with of PSII photosynthetic efficiency DeEll et al., (1999), the $\mathrm{Fv} / \mathrm{Fm}$ is normally in the range of 0.75 to 0.85 for nonstressed plants Bolhar-Nordenkampf et al., (1989). This is confirm our assumption that Zirconyl complex preservative created non stress environment for the flower stems. Chlorophyll fluorescence indicated the quantum yield of PSII during vase life, this fact and our results explains the higher levels of total soluble sugars in rose stem leaves. Another evidence explains that Zirconyl exhibit minimum toxicity to flower tissue is minimum, is free amino acids contents as plant treated with Zirconyl share the same values compared to control without significant differences. This means that, Zirconyl cause no further stress on plant tissues as plant under different stress condition tend to increase in the level of free amino acids Solanki and Sarangi, (2014).

The results in (Fig. 5) also indicates that the DPPH free radical Scavenging activity, of cut rose flower preserved with Zirconyl complex was initially low at the control treatment and increased gradually with increasing Zirconyl concentration. This effect was suggested by Schmitzer et al., (2010). Results also support the opinion of Lama et al., (2013) that, at the final stages of flower vase life, the low phenol content makes the flower more susceptible to oxidative stress. Plant treated with Zirconyl complex recorded lower phenolic contents except of $10 \mathrm{ppm}$ treatment. Meanwhile, total flavonoids content was enhanced by $20 \mathrm{ppm}$ treatment for efficiently mitigate oxidative stress management.

\section{CONCLUSION}

Form physiological point of view supported with the previous results, we could confirm that beside vase life improvement, using of Zirconyl complex as a floral preservative at low concentration 20-50 ppm improving flower water relation parameters as well as physiological and biochemical responses. As for our knowledge, this the first time to evaluate Zirconyl complex as a floral preservative. Further study is still needed to study its relation regarding antioxidant enzymes activity and stomata behavior. 


\section{REFERENCES}

Ahmad, I; Joyce, DC and Faragher, JD. (2011). Physical stem-end treatment effects on cut rose and acacia vase life and water relations. Postharvest Biology and Technology 59 258-264.

Bleeksma, HC and van Doorn, WG. (2003). Embolism in rose stems as a result of vascular occlusion by bacteria. Postharvest Biol. Technol. 29, 334-340.

Bolhar-Nordenkampf, HR; Long, SP; Baker, NR; Oquist, G; Schreiber, U and Lechner EG. (1989). Chlorophyll fluorescence as aprobe of the photosynthetic competence of leaves in the field: A review of current instrumentation. Funct. Ecol. $3: 497-514$

Brand-Williams, W; Cuvelier, ME and Berset, C. (1995). Use of free radical method to evaluate antioxidant activity. LWT-Food Science and Technology, 28, 25-30.

Bricker, B. (1991). MSTATC: A micro computer program from the design management and analysis of agronomic research experiments. Michigan State Univ.

Chang, C; Yang, M; Wen, H. and Chern, J. (2002). Estimation of total flavonoid content in propolis by two complementary colorimetric methods. J. Food Drug Anal. 10: 178-182.

Damunupola, JW and Joyce DC. (2006). When is a vase life solution biocide not, or not only, antimicrobial? J. Jpn. Soc. Hort. Sci. 77, 1-18.

DeEll, JR; Van Kooten, O; Prange, RK and Murr, DP. (1999). Application of chlorophyll fluorescence techniques in postharvest physiology. Hort. Rev. (Amer. Soc. Hort. Sci.) 23:69-107.

Harborne, JB. (1998). A guide to modern techniques of plant analysis. Phytochemical Methods, University of reading, UK. 3 edition, pp: 227.rd

He, SG; Joyce, DC; Irving, DE; and Faragher, JD. (2006). Stem-end blockage in cut Grevillea 'Crimson Yul-lo' inflorescences. Postharvest Biol. Technol. 41, 78-84.

Herbert, D; Phipps, PJ and Strange, RE. (1971): Determination of total carbohydrates. Method. Microbiol., 5, 290-344.

Jindal, KK and Singh, RN. (1975). Phenolic content in male and female Carica papaya: A possible physiological marker for sex identification of vegetable seedlings. Physiol. Plant. 33: 104-107.

Jowkar, MM; Kafi, M; Khalighi, A and Hasanzadeh, N. (2012). Evaluation of aluminum sulfate as vase solution biocide on postharvest microbial and physiological properties of 'Cherry Brandy' rose. Ann. Biolog. Res, 3 (2):1132-1144.

$$
\text { وجودة أزهار الورد بعد الحصاد }
$$

Khedr, AM; Gaber, M and Saad-allah KM. (2014). Synthesis, Characterization and Antimicrobial Efficiency of Some Zirconyl (II) Complexes Involving $\mathrm{O}$, N-Donor Environment of TriazoleBased Azodyes. Chinese J. of Inorg. Chemi. 30 (5): 1201-1211

Knee, M. (2000). Selection of biocides for use in floral preservatives Postharvest Biology and Technology 18 (2000) 227-234

Lama, B; Ghosal, M; Gupta, SK and Mandal, P. (2013). Assessment of Different Preservative Solutions on Vase Life of Cut Roses, J. of Ornam. Plants (J. of Ornam. and Horti. Plants), 3 (3): 171-181

Lee, YP and Takahashi, T. (1966). An improved colorimetric determination of amino acids with the use of ninhydrin. Analytical Biochemistry. 14(1): 71-73.

Liao, LJ; Huang, KL; Chen, WS and Cheng, YM. (2000). Postharvest life of cut rose flowers as affected by silver thiosulfate and sucrose. Botanical Bulletin Academica Sinica. 41: 299303.

Liu, J; He, S; Zhang, Z; Cao, J; Lv, P; He, S; Cheng, G and Joyce DC. (2009). Nano-silver pulse treatments inhibit stem-end bacteria on cut Gerbera cv. Ruikou flowers Postharvest Biology and Technology, 54 (1): 59-62.

Sadasivam, S and Manickam A. (1992). Biochemical methods for agriculture sciences. Wiley Eastern limited. PP. 181-185.

Schmitzer, V; Veberic, R; Osterc, Gand Stampar, F. (2010). Color and phenolic content changes during flower development in ground cover rose. J. Amer. Soc. Hort. Sci. 135(3): 195-202.

Sendecor, GW and Cochran, WG. (1982). Statistical Methods. The Iowa State Univ., Press. Ames., Iowa, U.S.A., 507 pp.

Shaman, NT. (2012) application of essential oils to prolong the vase life of Rose (Rosa Hybrida L. cv. "grand") cut flower. Journal of Horticultural science \& ornamental plants 4 (1):66-74.

Solanki, JK and Sarangi, SK. (2014). Effect of drought stress on proline accumulation in peanut genotypes. Iintern. J. of Advan. Res. (2) 10: 301309.

Torre, S and Fjeld, T. (2001). Water loss and postharvest characteristics of cut roses grown at high or moderate relative air humidity", SCI HORT A, 89(3): 217-226

Van Doorn, W. G. (1996) Water Relations of Cut Flowers, in Horticultural Reviews, Vol. 18, (John Wiley and Sons Inc, New York, USA., 1997, 185 .

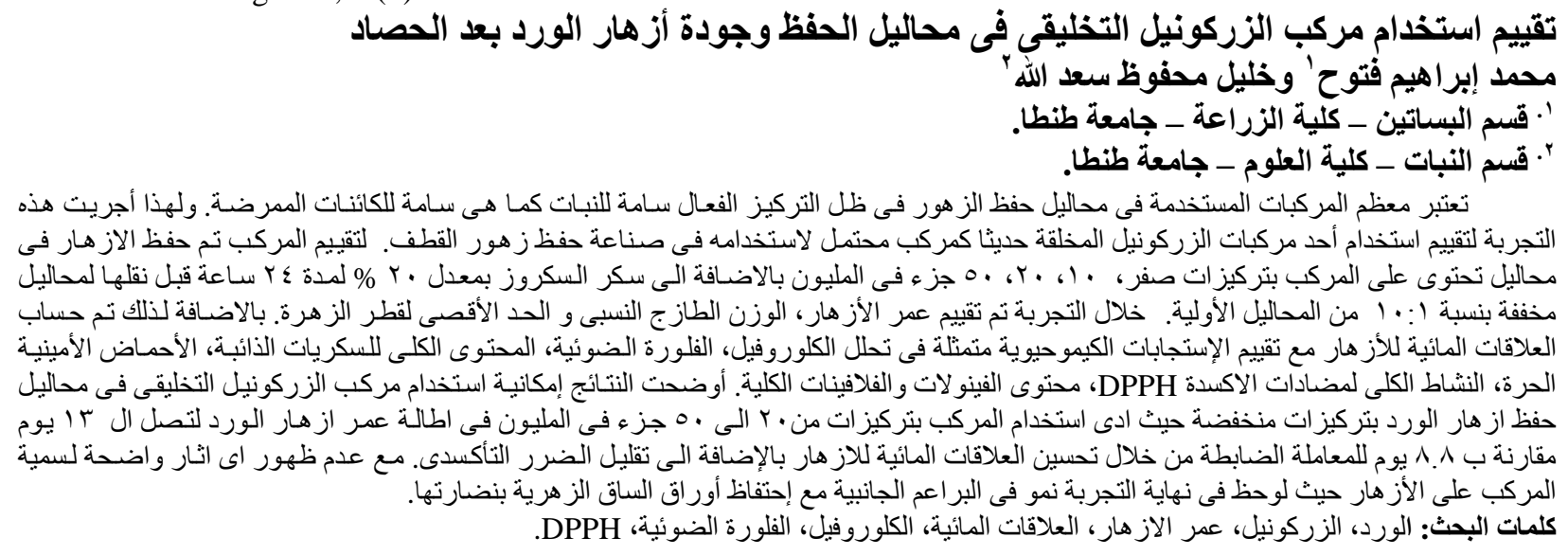

